\title{
Assessment of Radiation Dose Caused by Radioactive Gaseous Effluent Released from Nuclear Power Plant Ninh Thuan 1 under Scenario of Normal Working Conditions
}

\author{
Nguyen Tuan Khai', Do Xuan Anh', Le Dinh Cuong1, Duong Duc Thang1, Vuong Thu Bac1, \\ Nguyen Thi Thu Ha1, Nguyen Quang Long1, Trinh Van Giap1, Nguyen Hao Quang2 \\ ${ }^{1}$ Institute for Nuclear Science and Technology (INST), Hanoi, Vietnam \\ ${ }^{2}$ Vietnam Atomic Energy Institute (VINATOM), Hanoi, Vietnam \\ Email: ntkhai@iop.vast.ac.vn
}

Received 23 June 2015; accepted 17 July 2015; published 20 July 2015

Copyright (C) 2015 by authors and Scientific Research Publishing Inc.

This work is licensed under the Creative Commons Attribution International License (CC BY).

http://creativecommons.org/licenses/by/4.0/

(c) (i) Open Access

\begin{abstract}
Based on guides RG 1.109, RG 1.111 published by United States Nuclear Regulatory Commission (USNRC), our research concentrates in assessing radiation doses caused by radioactive substances released from the nuclear power plant (NPP) Ninh Thuan 1 under the scenario of normal operation using software package NRCDose 72 provided by the USNRC. The database including the released radioactive nuclides, meteorology, terrain, population and agricultural production activities have been collected and processed to build the input data for the model calculation. The wind rose distribution obtained from the meteorological data in a five-year period from 2009-2013 showed that the radioactive nuclides released to environment spread in two main wind directions which are North East and South West. The $X / Q\left(\mathrm{~s} / \mathrm{m}^{3}\right)$ and $D / Q\left(\mathrm{~s} / \mathrm{m}^{2}\right)$ qualities which are, respectively, the ratio of activity concentration to release rate and that of deposition density of radioactive nuclides to release rate were calculated within an area of $80 \mathrm{~km}$ radius from the NPP site using XOQDOQ. Population doses were calculated using GASPAR. The XOQDOQ and GASPAR are two specific softwares in NRCDose 72 package.
\end{abstract}

\section{Keywords}

NPP, Radioactive Release, Radiation Dose, Population Dose, $X / Q$ and $D / Q$ 


\section{Introduction}

In November 2009, the National Assembly of Vietnam approved the resolution on the first two nuclear power plant (NPP) projects, namely Ninh Thuan 1 \& 2, with a total capacity of $2000 \mathrm{MW}$ for each. At present, the Vietnam Government has decided the foreign partner for the project Ninh Thuan 1 is Russian Federation and for Ninh Thuan 2 is Japan. For the project Ninh Thuan 1, the VVER-AES2006 reactor technology was proposed for selection and the plant site was decided at Phuoc Dinh village, Thuan Nam district, Ninh Thuan province. The technology selection for the project Ninh Thuan 2 is under consideration.

When going into operation, the NPP will release radioactive nuclides into the atmosphere. The radioactive effluent undergoing dispersion in air and deposition on ground will cause impact to the environment and human. Therefore, study on transport and dispersion of the radioactive substances in the atmosphere, and assessment for radiation dose to the publics are of essential requirement for an NPP project. In addition, the calculation results will provide the necessary data for the Environmental Impact Assessment (EIA) and support for regulatory organization in reviewing the Safety Analysis Report (SAR).

Radioactive releases from various nuclear facilities, in general, may contribute to radiation exposure through two main pathways: 1) External exposures by direct radiation from radioactive plumes or from radioactive nuclides deposited on the ground, and 2) Internal exposure due to inhalation and ingestion of radioactive substances. The magnitude of exposure depends on atmospheric dispersion and deposition processes.

In this work, we concentrate on investigating the radioactive release from the NPP Ninh Thuan 1, which is assumed to use the VVER-1200 (AES2006) technology, and assessing radiation doses for the population under the scenario of normal working conditions using software package NRCDose72. To build the data input for the model calculations the database on meteorology, terrain, population and agricultural production activities has been collected and processed within a scope of $80 \mathrm{~km}$ from the plant site, where the wind rose distribution was obtained from processing the meteorological data in a five-year period of 2009-2013. The source term of released radioactive nuclides was evaluated using Gale code, a software in the NRCDose72 package. The calculated result is compared with the statistic data base on the annual normalized release in $\mathrm{Bq} /\left(\mathrm{GW}_{\mathrm{e}}\right.$-year) for the PWR reactor type based on the average evaluation on a period from 1990-1997 provided by the United Nations Scientific Committee on the Effects of Atomic Radiation (UNSCEAR) [1] [2]. The ratio of activity concentrations $X / Q\left(\mathrm{~s} / \mathrm{m}^{3}\right)$ and that of radioactive deposition densities $D / Q\left(\mathrm{~s} / \mathrm{m}^{2}\right)$ were calculated using XOQDOQ, in which it is assumed that the radioactive substance is dispersed by the Gaussian model. The obtained results on $X / Q$ and $D / Q$ values were used for evaluating the population doses using GASPAR. The XOQDOQ and GASPAR are two softwares in NRCDose72 package [3] [4].

\section{Computer Code Description}

\subsection{XOQDOQ}

Computation program XOQDOQ is used in the independent meteorological evaluation of routine or anticipated, intermittent releases of radioactive nuclides at commercial nuclear power plants. It is primarily designed to calculate annual relative effluent concentrations, $X / Q$ values, and annual average relative deposition, $D / Q$ values, at locations specified by the user, and at various standard radial distances and segments for downwind sectors. Evaluations of anticipated intermittent (e.g. containment or purge) releases which occur during routine operation may also be evaluated using the program. Evaluation of intermittent releases provides both $X / Q$ and $D / Q$ values at various standard locations, as well as user-inputted specific points of interest.

The input of the program includes meteorological and topographic data. Meteorological data is as a joint frequency table, i.e. a table of the fractional occurrence during a given time period of a particular combination of stability class type, wind direction, and wind speed class. The wind direction is classified into 16 sectors proceeding clockwise from $\mathrm{N}$ through NNW. The wind speeds are grouped into classes, with the program allowing up to 14 separate classes, which include a class for calm wind speeds. Atmospheric stability is grouped according to seven categories from extremely unstable to extremely stable. Terrain elevation (in meters, compared to the factory floor) is the maximum height in the topographic data collected in the $80 \mathrm{~km}$ radius from the NPP site. The direction and distance from the source are included in terrain elevation data.

In this work the meteorological data at Ninh Thuan including wind direction, wind speed and atmospheric stability has been collected and processed based on a five-year database provided by Phan Rang meteorological 
station. The terrain data is built using the topographic map within the $80 \mathrm{~km}$ radius around the NPP site.

The values $X / Q$ is determined by the following formula [3]:

$$
\frac{X}{Q}(x, K)=\frac{2.032}{x} \times R F(x, K) \sum_{i, j}^{N, 7} \frac{D E P L_{i j}(x, K) D E C_{i}(x) f_{i j}(K)}{U_{i}(x) \sigma_{Z j}(x)} \times \exp \left(-0.5\left(\frac{h_{e}^{2}}{\sigma_{z j(x)}^{2}}\right)\right)
$$

where $\frac{X}{Q}(x, K)$ is average effluent concentration normalized by source strength at distance $x$ in directional sector $K\left(\mathrm{~s} / \mathrm{m}^{3}\right) ; x$ is the downwind distance (meters); $i$ is the $i^{\text {th }}$ wind-speed class; $j$ is the $j^{\text {th }}$ atmospheric stability class; $K$ is the $k^{\text {th }}$ wind-direction class; $U_{i}$ is mid-point value of the $i^{\text {th }}$ wind-speed class; $\sigma_{Z j}(x)$ is the vertical plume spread for stability class $j$ at distance $x ; f_{i j}(K)$ is the joint probability of occurrence of the $i^{\text {th }}$ wind-speed class, $j^{\text {th }}$ is stability class, and $K^{\text {th }}$ is wind direction sector; $h_{e}$ is the effective plume height (in meters); $D E C_{i}(x)$ is the reduction factor due to radioactive decay at distance $x$ for the $i^{\text {th }}$ wind-speed class; $D \operatorname{EPL}(x, K)$ is the reduction factor due to plume depletion at distance $x$ for the $i^{\text {th }}$ wind-speed class, $j^{\text {th }}$ stability class and $K^{\text {th }}$ wind-direction class; $R F(x, K)$ is the correction factor for recirculation and stagnation at downwind distance $x$ and $K^{\text {th }}$ winddirection class.

For each directional sector, relative deposition is computed by the following relationship for a specific downwind distance [3]:

$$
\frac{D}{Q}(x, K)=\frac{R F(x, K) \sum_{i, j}^{N, 7} D_{i j} f_{i j}(K)}{\left(\frac{2 \pi}{16}\right) x}
$$

where $\frac{D}{Q}(x, K)$ is the average relative deposition per unit area at a downwind distance $x$ and direction $K$, in me$\operatorname{ter}^{-2} ; D_{i j}$ is the relative deposition rate for the $i^{\text {th }}$ wind-speed class and the $j^{\text {th }}$ stability class; $f_{i j}(K)$ is the joint probability of occurrence of the $i^{\text {th }}$ wind-speed class; $R F(x, K)$ is the correction factor for recirculation and stagnation at downwind distance $x$ and $K^{\text {th }}$ wind-direction class.

\subsection{GASPAR}

GASPAR is a computer code used by the USNRC in radiation dose assessment for individuals and groups of people contaminated by the release of radioactive nuclides into the air environment of nuclear power plants in normal operation conditions. The theoretical basis for the radiation dose calculations of the code is based on Regulatory Guide 1.109 and NUREG/CR-4653 [5] [6].

In this work we have built the data input of the code calculations, including:

1) Population: Data on the total population and population distribution for four distinct age groups: infant, child, teenager and adult in each sector (subregion);

2) Crop and cattle breeding: Data on production and distributions of meat, milk and production; These two data sets were processed within the $80 \mathrm{~km}$ radius around the NPP site.

3) Radioactive release: Data on the activity ( $\mathrm{Ci}$ ) of theradioactive nuclides released to the environment and the rate of the radioactive waste (Ci/year);

4) Meteorology:

- Data on atmospheric dispersion parameters $\left(\mathrm{sec} / \mathrm{m}^{3}\right)$ for use in population dose calculations for the undecayed/undepleted dispersion and the decayed/undepleted dispersion;

- Data on atmospheric dispersion parameters $\left(\mathrm{sec} / \mathrm{m}^{3}\right)$ with decay and depletion for use in population dose calculations for the decayed/depleted dispersion;

- Data on ground deposition parameter $\left(\mathrm{m}^{-2} /\right.$ year) for use in population dose calculations;

It should be noted that the meteorological data can be imported either directly into the software or from the output of XOQDOQ software.

The outputs of GASPAR include:

- Gamma air and beta air dose;

- Annual effective dose from all other noble gas releases;

- Skin dose; 
- Annual organ dose from external irradiation by deposited radioactive nuclides;

- Annual organ dose from inhalation;

- Annual organ dose from ingestion of radioactive nuclides in food;

- Annual population integrated dose.

\section{Results and Discussion}

\subsection{Meteorological Data Processing}

Based on the database provided by the Phan Rang station in the five-year period from 2009 to 2013 the meteorological data was processed to obtain the wind rose distribution as shown in Figure 1 for the wind direction and speed in the area planned for construction of the NPP Ninh Thuan 1 . We can see that the wind direction and intensity is mainly concentrated on two directions of the North East and South West. These are two main wind directions passing through the provinces of the region in the South Central Coast and Central Highlands.

As known, the stability classes are computed from wind speed, daytime incoming solar radiation (ISR) and cloudiness observed at meteorological stations. In this work, the data is obtained from Phan Rang meteorological station which is the closest meteorological station to the site of the plant Ninh Thuan 1. Unfortunately, the observed ISR is not available at Phan Rang station. So, we have evaluated computationally the ISR using experimental method of Black (1956) as suggested by Quinn and Burt (1967) in which the ISR is experimentally defined from location of Phan Rang station (11.35N, 108.59E) and cloudiness as [7] [8]:

$$
Q=Q_{A}\left(0.803-0.340 C-0.458 C^{2}\right)
$$

In which, $Q$ is ISR at the surface, $C$ is cloudiness in oktas.

$Q_{A}$ is ISR at the top of atmosphere defined from location of Phan Rang station as:

$$
Q_{A}=S_{o}(\sin \varnothing \sin d+\cos \varnothing \cos d \cosh ) / r^{2}
$$

$S_{o}=1367 \mathrm{~W} / \mathrm{m}^{2}$ is solar constant, $\varnothing$ is station latitude, $d$ is the declination of the sun, $h$ is hour angle, $r$ is the earth's radius vector (the actual distance between the centers of the earth and the sun divided by the mean distance between them).

Terrain elevation (in meters, compared to the factory floor) is processed as the maximum height in the topographic data using the topographic map collected within the $80 \mathrm{~km}$ radius from the NPP site.

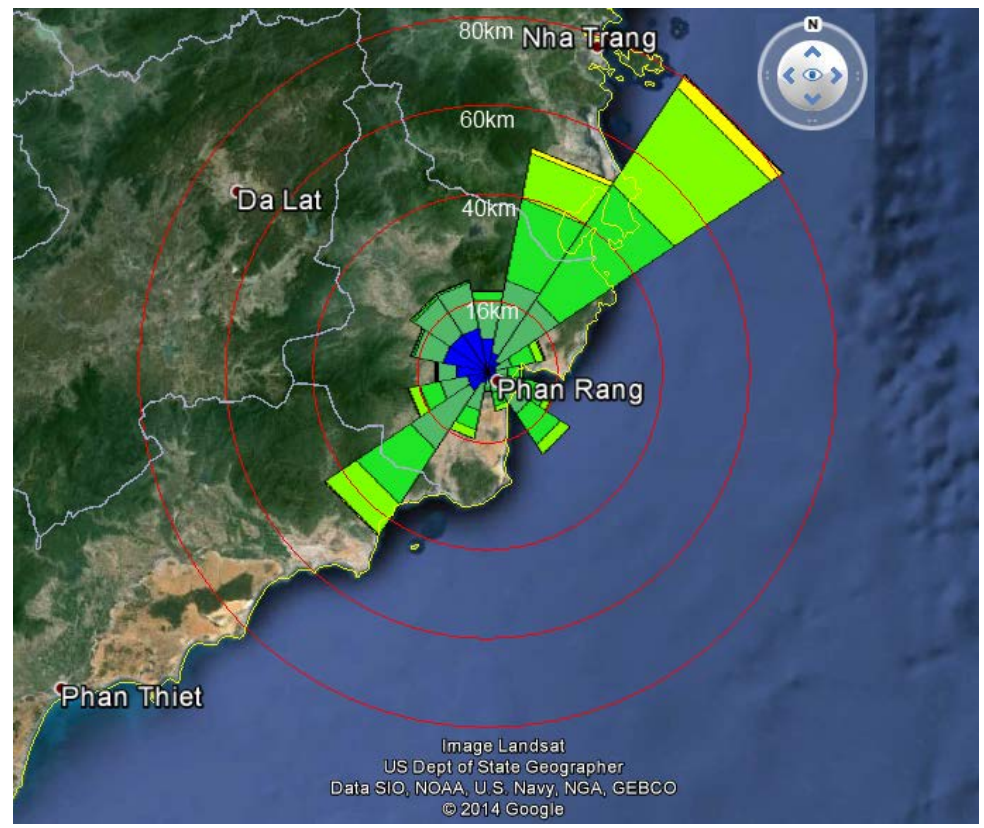

Figure 1. The wind rose distribution obtained from the database of the Phan Rang station. 


\subsection{Gaseous Effluent Distribution}

The output from the program XOQDOQ was designed to present the maximum amount of information on each release point, including:

- $X / Q\left(\mathrm{~s} / \mathrm{m}^{3}\right)$ and $D / Q\left(\mathrm{~s} / \mathrm{m}^{2}\right)$ values at 22 specific distances ranging from 0.80 to $80 \mathrm{~km}$;

- $X / Q$ and $D / Q$ values for 10 distance intervals;

- $X / Q$ and $D / Q$ values at specific points of interest.

The obtained calculation results made us possible to build the $X / Q$-value and $D / Q$-value distributions as a function of distance ranging from 0.8 to $80 \mathrm{~km}$ from the plant site as shown in Figure 2. We can see clearly that the $X / Q$ and $D / Q$ values are dominant in two directions of North East and South West. This is consistent with the obtained wind rose distribution, where the wind frequencies are also high in these two directions (Figure 1).

\subsection{Population Dose Assessment}

The output of the program GASPAR gives the calculation results for the annual integrated population dose and annual individual dose for three distinct age groups including child, teenager and adult at the locations of interest. The details are given in Tables 1-3.

We can see that the obtained results for dose evaluation induced by the released radioactive nuclides from the NPP Ninh Thuan 1 are much lower than the limit value of $1.0 \mathrm{mSv}$ for publics specified by the documents of Vietnam Regulatory Organization and USNRC [9] [10].

The annual individual dose values given in Table 3 show a quickly decreasing tendency with respect to distance, for example the dose difference between Vinh Tuong and Lien Nghia which are the nearest and farthest locations from the plant site is about 2orders.

From the obtained calculation results shown in Tables 1-3 we can see that:

- From Table 1: The dose induced by the plume gives the greatest contribution, from about $20 \%$ for thyroid to about $80 \%$ for skin, to the annual integrated population dose.This can be naturally understandable, especially for skin induced by a direct expose from the plume.

It is also noted that the dose contribution from rice and vegetable is quite high, from about $11 \%$ for the skin to

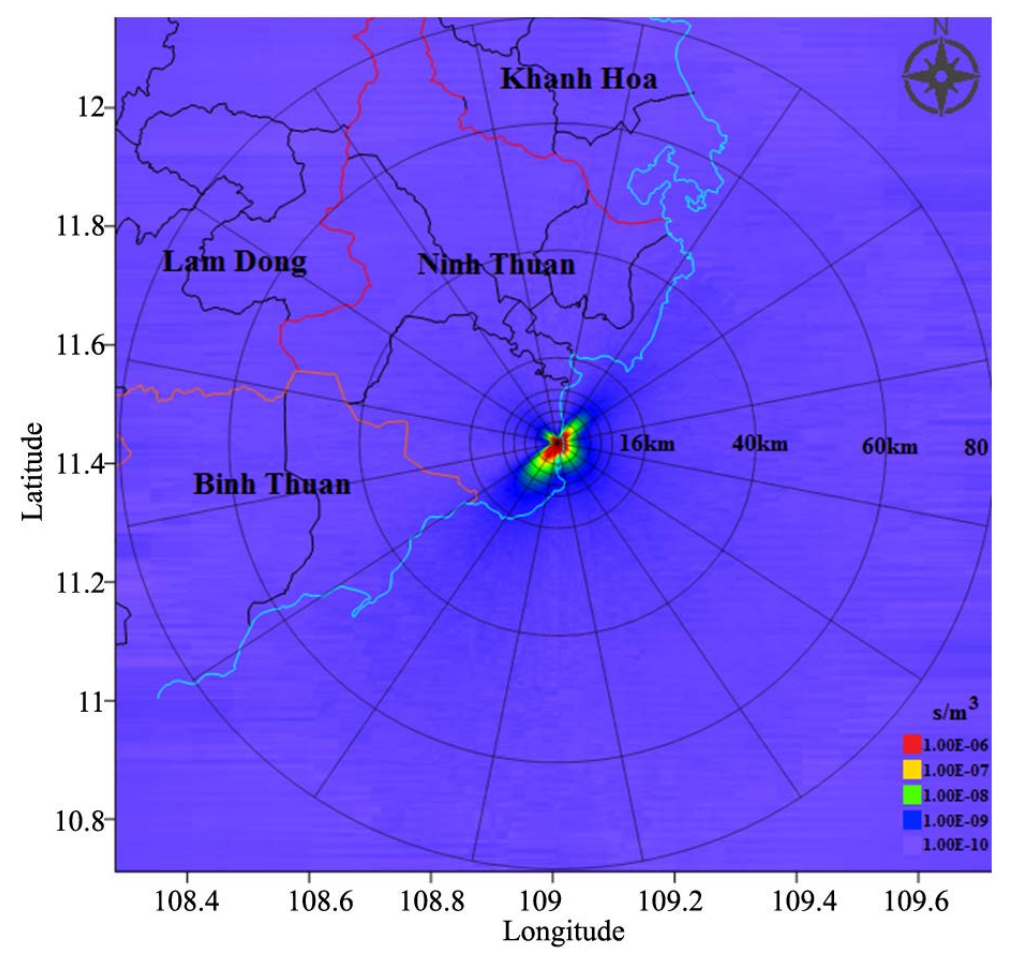

Figure 2. $X / Q$ value distribution within $80 \mathrm{~km}$ from the site. 
Table 1. Calculation results for annual integrated population dose in $80 \mathrm{~km}$ radius.

\begin{tabular}{|c|c|c|c|c|c|c|c|c|}
\hline \multirow{2}{*}{ Pathway } & \multicolumn{8}{|c|}{ Annual total population dose (person-mSv) } \\
\hline & Effective & Gi-lli & Bone & Liver & Kidney & Thyroid & Lung & Skin \\
\hline \multirow[t]{2}{*}{ Plume } & $5.16 \mathrm{E}-2$ & $5.16 \mathrm{E}-2$ & $5.16 \mathrm{E}-2$ & $5.16 \mathrm{E}-2$ & $5.16 \mathrm{E}-2$ & $5.16 \mathrm{E}-2$ & $5.70 \mathrm{E}-02$ & $5.44 \mathrm{E}-1$ \\
\hline & $27.33 \%$ & $27.26 \%$ & $27.94 \%$ & $28.30 \%$ & $28.31 \%$ & $18.88 \%$ & $30.39 \%$ & $79.77 \%$ \\
\hline \multirow[t]{2}{*}{ Ground } & $5.78 \mathrm{E}-3$ & $5.78 \mathrm{E}-3$ & $5.78 \mathrm{E}-3$ & $5.78 \mathrm{E}-3$ & $5.78 \mathrm{E}-3$ & $5.78 \mathrm{E}-3$ & $5.78 \mathrm{E}-03$ & $1.16 \mathrm{E}-2$ \\
\hline & $3.06 \%$ & $3.06 \%$ & $3.13 \%$ & $3.17 \%$ & $3.17 \%$ & $2.12 \%$ & $3.08 \%$ & $1.70 \%$ \\
\hline \multirow[t]{2}{*}{ Inhalation } & $2.18 \mathrm{E}-2$ & $2.16 \mathrm{E}-2$ & $2.16 \mathrm{E}-2$ & $2.16 \mathrm{E}-2$ & $2.16 \mathrm{E}-2$ & $2.72 \mathrm{E}-2$ & $2.16 \mathrm{E}-02$ & $2.16 \mathrm{E}-2$ \\
\hline & $11.59 \%$ & $11.40 \%$ & $11.70 \%$ & $11.84 \%$ & $11.84 \%$ & $9.98 \%$ & $11.51 \%$ & $3.16 \%$ \\
\hline \multirow[t]{2}{*}{$\begin{array}{l}\text { Rice and } \\
\text { Vegetable }\end{array}$} & $7.48 \mathrm{E}-2$ & $7.80 \mathrm{E}-2$ & $7.54 \mathrm{E}-2$ & $7.32 \mathrm{E}-2$ & $7.32 \mathrm{E}-2$ & $7.66 \mathrm{E}-2$ & $7.32 \mathrm{E}-02$ & $7.44 \mathrm{E}-2$ \\
\hline & $39.65 \%$ & $41.28 \%$ & $40.90 \%$ & $40.20 \%$ & $40.19 \%$ & $28.07 \%$ & $39.01 \%$ & $10.90 \%$ \\
\hline \multirow[t]{2}{*}{ Cowmilk } & $5.01 \mathrm{E}-3$ & $3.45 \mathrm{E}-3$ & $3.24 \mathrm{E}-3$ & $3.21 \mathrm{E}-3$ & $3.21 \mathrm{E}-3$ & $3.87 \mathrm{E}-2$ & $3.21 \mathrm{E}-03$ & $3.25 \mathrm{E}-3$ \\
\hline & $5.31 \%$ & $3.65 \%$ & $3.51 \%$ & $3.53 \%$ & $3.53 \%$ & $28.35 \%$ & $3.43 \%$ & $0.95 \%$ \\
\hline \multirow[t]{2}{*}{ Meat } & $2.46 \mathrm{E}-2$ & $2.52 \mathrm{E}-2$ & $2.36 \mathrm{E}-2$ & $2.36 \mathrm{E}-2$ & $2.36 \mathrm{E}-2$ & $3.44 \mathrm{E}-2$ & $2.36 \mathrm{E}-02$ & $2.40 \mathrm{E}-2$ \\
\hline & $13.05 \%$ & $13.36 \%$ & $12.82 \%$ & $12.97 \%$ & $12.97 \%$ & $12.61 \%$ & $12.58 \%$ & $3.52 \%$ \\
\hline Total & $1.89 \mathrm{E}-1$ & $1.89 \mathrm{E}-1$ & $1.85 \mathrm{E}-1$ & $1.82 \mathrm{E}-1$ & $1.82 \mathrm{E}-1$ & $2.74 \mathrm{E}-1$ & $1.88 \mathrm{E}-01$ & $6.82 \mathrm{E}-1$ \\
\hline
\end{tabular}

about $40 \%$ for the other organs. This is consistent with the agricultural production activities in the Ninh Thuan region.

- From Table 2: The radioactive isotopes ${ }^{14} \mathrm{C}$ and ${ }^{3} \mathrm{H}$ induce the greatest contributions to the annual total population dose. This can be naturally understandable because two these isotopes with the very long half-lives are produced by the typical nuclear reactions in moderator and reactor core materials, such as ${ }^{13} \mathrm{C}(\mathrm{n}, \gamma){ }^{14} \mathrm{C},{ }^{14} \mathrm{~N}(\mathrm{n}$, p) ${ }^{14} \mathrm{C},{ }^{15} \mathrm{~N}(\mathrm{n}, \mathrm{d}){ }^{14} \mathrm{C},{ }^{16} \mathrm{O}\left(\mathrm{n},{ }^{3} \mathrm{He}\right){ }^{14} \mathrm{C}$ and ${ }^{17} \mathrm{O}(\mathrm{n}, \alpha){ }^{14} \mathrm{C}$ for ${ }^{14} \mathrm{C}$, and ${ }^{2} \mathrm{H}(\mathrm{n}, \gamma){ }^{3} \mathrm{H},{ }^{6} \mathrm{Li}(\mathrm{n}, \alpha){ }^{3} \mathrm{H},{ }^{14} \mathrm{~N}\left(\mathrm{n},{ }^{3} \mathrm{H}\right){ }^{12} \mathrm{C}$ and also ternary fission mode for ${ }^{3} \mathrm{H}$ [11].

For the fission products we can see the greatest contributions are from two radioactive isotopes ${ }^{133,135} \mathrm{Xe}$. This is because two these isotopes have relatively high fission yields. In addition, it should be noted that ${ }^{60} \mathrm{Co}$ induces a typical dose contribution amongst the radioactive isotopes produced from neutron-induced activation reactions on the reactor core materials. These activation products release via corrosion phenomenon [11].

- From Table 3: The effective dose for the child is about 1.7 and 2.3 times, respectively, greater than those for the teenager and adult. This is due to the fact that children are clearly more radiosensitive than adults. This conclusion was found in UNSCEAR 2013 Report [12], where it is shown that for a given radiation dose, children are generally at more risk of tumour induction than are adults. Estimates of lifetime cancer risk for those exposed as children were uncertain and might be a factor of 2 to 3 times as high as estimates for a population exposed at all ages [12]. In addition, in the Gastrointestinal (GI) tract model used for calculating doses from ingested radionuclides for children and adults, it is recognized that the transit times of material through the GI tract are age-dependent. The mean gastrointestinal transit time in children is significantly less than that in adults. As a consequence, the effective dose induced by the ingested radionuclides for the children is greater than that for adults [13].

Based on the calculation results for the annual dose evaluations and analysis for the dose contributions within the $80 \mathrm{~km}$ radius from the plant we can conclude that the gaseous effluent release from the NPP Ninh Thuan 1 in the normal working conditions satisfies the requirements on radiation safety for population and production activities.

\section{Conclusions}

We have built the data inputs for two computer codes XOQDOQ and GASPAR based on collecting and processing a huge database including the data on population and population distribution for distinct age groups, 
Table 2. Calculation results for annual integrated population dose induced by the released radionuclides.

\begin{tabular}{|c|c|c|c|c|c|c|c|c|}
\hline \multirow{2}{*}{$\begin{array}{c}\text { Radioactive } \\
\text { nuclide }\end{array}$} & \multicolumn{8}{|c|}{ Annual total population dose (person-mSv) } \\
\hline & Effective & Gi-lli & Bone & Liver & Kidney & Thyroid & Lung & Skin \\
\hline \multirow[t]{2}{*}{${ }^{3} \mathrm{H}$} & $4.20 \mathrm{E}-2$ & $4.20 \mathrm{E}-2$ & $4.20 \mathrm{E}-2$ & $4.20 \mathrm{E}-2$ & $4.20 \mathrm{E}-2$ & $4.20 \mathrm{E}-2$ & $4.20 \mathrm{E}-2$ & $4.20 \mathrm{E}-2$ \\
\hline & $22.28 \%$ & $22.21 \%$ & $22.77 \%$ & $23.06 \%$ & $23.07 \%$ & $15.39 \%$ & $22.40 \%$ & $6.16 \%$ \\
\hline \multirow[t]{2}{*}{${ }^{14} \mathrm{C}$} & $8.44 E-2$ & $8.90 E-2$ & $8.26 \mathrm{E}-2$ & $8.26 \mathrm{E}-2$ & $8.26 \mathrm{E}-2$ & $8.26 \mathrm{E}-2$ & $8.26 \mathrm{E}-2$ & $8.44 E-2$ \\
\hline & $44.74 \%$ & $47.02 \%$ & $44.75 \%$ & $45.32 \%$ & $45.34 \%$ & $30.24 \%$ & $44.02 \%$ & $12.37 \%$ \\
\hline \multirow[t]{2}{*}{${ }^{41} \mathrm{Ar}$} & $3.12 \mathrm{E}-3$ & $3.12 \mathrm{E}-3$ & $3.12 \mathrm{E}-3$ & $3.12 \mathrm{E}-3$ & $3.12 \mathrm{E}-3$ & $3.12 \mathrm{E}-3$ & $3.12 \mathrm{E}-3$ & $1.48 \mathrm{E}-2$ \\
\hline & $1.65 \%$ & $1.65 \%$ & $1.69 \%$ & $1.71 \%$ & $1.71 \%$ & $1.14 \%$ & $1.66 \%$ & $2.16 \%$ \\
\hline \multirow[t]{2}{*}{${ }^{131} \mathrm{I}$} & $4.54 \mathrm{E}-3$ & $2.26 \mathrm{E}-4$ & $2.08 \mathrm{E}-4$ & $1.99 \mathrm{E}-4$ & $1.98 \mathrm{E}-4$ & $8.86 \mathrm{E}-2$ & $2.08 \mathrm{E}-4$ & $3.36 \mathrm{E}-4$ \\
\hline & $2.41 \%$ & $0.12 \%$ & $0.11 \%$ & $0.11 \%$ & $0.11 \%$ & $32.47 \%$ & $0.11 \%$ & $0.05 \%$ \\
\hline \multirow[t]{2}{*}{${ }^{133} \mathrm{I}$} & $2.34 \mathrm{E}-4$ & $1.05 \mathrm{E}-4$ & $1.05 \mathrm{E}-4$ & $1.04 \mathrm{E}-4$ & $1.04 \mathrm{E}-4$ & $2.60 \mathrm{E}-3$ & $1.06 \mathrm{E}-4$ & $7.60 \mathrm{E}-4$ \\
\hline & $0.12 \%$ & $0.06 \%$ & $0.06 \%$ & $0.06 \%$ & $0.06 \%$ & 0.95\% & $0.06 \%$ & $0.11 \%$ \\
\hline \multirow[t]{2}{*}{${ }^{85 \mathrm{~m}} \mathrm{Kr}$} & $8.34 \mathrm{E}-4$ & $8.34 \mathrm{E}-4$ & $8.34 \mathrm{E}-4$ & $8.34 \mathrm{E}-4$ & $8.34 \mathrm{E}-4$ & $8.34 \mathrm{E}-4$ & $8.74 \mathrm{E}-4$ & $6.86 \mathrm{E}-3$ \\
\hline & $0.44 \%$ & $0.44 \%$ & $0.45 \%$ & $0.46 \%$ & $0.46 \%$ & $0.31 \%$ & $0.47 \%$ & $1.01 \%$ \\
\hline \multirow[t]{2}{*}{${ }^{85} \mathrm{Kr}$} & $1.23 \mathrm{E}-3$ & $1.23 \mathrm{E}-3$ & $1.23 \mathrm{E}-3$ & $1.23 \mathrm{E}-3$ & $1.23 \mathrm{E}-3$ & $1.23 \mathrm{E}-3$ & $2.88 \mathrm{E}-3$ & $1.36 \mathrm{E}-1$ \\
\hline & $0.65 \%$ & $0.65 \%$ & $0.67 \%$ & $0.68 \%$ & $0.68 \%$ & $0.45 \%$ & $1.54 \%$ & $20.01 \%$ \\
\hline \multirow[t]{2}{*}{${ }^{87} \mathrm{Kr}$} & $1.05 \mathrm{E}-3$ & $1.05 \mathrm{E}-3$ & $1.05 \mathrm{E}-3$ & $1.05 \mathrm{E}-3$ & $1.05 \mathrm{E}-3$ & $1.05 \mathrm{E}-3$ & $1.10 \mathrm{E}-3$ & $8.78 \mathrm{E}-3$ \\
\hline & $0.56 \%$ & $0.55 \%$ & $0.57 \%$ & $0.58 \%$ & $0.58 \%$ & $0.38 \%$ & $0.58 \%$ & $1.29 \%$ \\
\hline \multirow[t]{2}{*}{${ }^{88} \mathrm{Kr}$} & $1.29 \mathrm{E}-2$ & $1.29 \mathrm{E}-2$ & $1.29 \mathrm{E}-2$ & $1.29 \mathrm{E}-2$ & $1.29 \mathrm{E}-2$ & $1.29 \mathrm{E}-2$ & $1.30 \mathrm{E}-2$ & $5.52 \mathrm{E}-2$ \\
\hline & $6.83 \%$ & $6.81 \%$ & $6.98 \%$ & $7.07 \%$ & $7.07 \%$ & $4.71 \%$ & $6.90 \%$ & $8.10 \%$ \\
\hline \multirow[t]{2}{*}{${ }^{131 \mathrm{~m}} \mathrm{Xe}$} & $1.45 \mathrm{E}-3$ & $1.45 \mathrm{E}-3$ & $1.45 \mathrm{E}-3$ & $1.45 \mathrm{E}-3$ & $1.45 \mathrm{E}-3$ & $1.45 \mathrm{E}-3$ & $2.24 \mathrm{E}-3$ & $4.62 \mathrm{E}-2$ \\
\hline & $0.77 \%$ & $0.77 \%$ & $0.79 \%$ & $0.80 \%$ & $0.80 \%$ & $0.53 \%$ & $1.19 \%$ & $6.76 \%$ \\
\hline \multirow[t]{2}{*}{${ }^{133 m} \mathrm{Xe}$} & $3.38 \mathrm{E}-4$ & $3.38 \mathrm{E}-4$ & $3.38 \mathrm{E}-4$ & $3.38 \mathrm{E}-4$ & $3.38 \mathrm{E}-4$ & $3.38 \mathrm{E}-4$ & $4.04 \mathrm{E}-4$ & $6.30 \mathrm{E}-3$ \\
\hline & $0.18 \%$ & $0.18 \%$ & $0.18 \%$ & $0.19 \%$ & $0.19 \%$ & $0.12 \%$ & $0.21 \%$ & $0.92 \%$ \\
\hline \multirow[t]{2}{*}{${ }^{133} \mathrm{Xe}$} & $1.68 \mathrm{E}-2$ & $1.68 \mathrm{E}-2$ & $1.68 \mathrm{E}-2$ & $1.68 \mathrm{E}-2$ & $1.68 \mathrm{E}-2$ & $1.68 \mathrm{E}-2$ & $1.90 \mathrm{E}-2$ & $1.68 \mathrm{E}-1$ \\
\hline & $8.89 \%$ & $8.86 \%$ & $9.08 \%$ & $9.20 \%$ & $9.20 \%$ & $6.14 \%$ & $10.14 \%$ & $24.60 \%$ \\
\hline \multirow[t]{2}{*}{${ }^{135 m} \mathrm{Xe}$} & $5.90 \mathrm{E}-5$ & $5.90 \mathrm{E}-5$ & $5.90 \mathrm{E}-5$ & $5.90 \mathrm{E}-5$ & $5.90 \mathrm{E}-5$ & $5.90 \mathrm{E}-5$ & $5.94 \mathrm{E}-5$ & $2.84 \mathrm{E}-4$ \\
\hline & $0.03 \%$ & $0.03 \%$ & $0.03 \%$ & $0.03 \%$ & $0.03 \%$ & $0.02 \%$ & $0.03 \%$ & $0.04 \%$ \\
\hline \multirow[t]{2}{*}{${ }^{135} \mathrm{Xe}$} & $1.37 \mathrm{E}-2$ & $1.37 \mathrm{E}-2$ & $1.37 \mathrm{E}-2$ & $1.37 \mathrm{E}-2$ & $1.37 \mathrm{E}-2$ & $1.37 \mathrm{E}-2$ & $1.42 \mathrm{E}-2$ & $1.01 \mathrm{E}-1$ \\
\hline & $7.25 \%$ & $7.23 \%$ & $7.41 \%$ & $7.51 \%$ & $7.51 \%$ & $5.01 \%$ & $7.57 \%$ & $14.75 \%$ \\
\hline \multirow[t]{2}{*}{${ }^{138} \mathrm{Xe}$} & $1.60 \mathrm{E}-4$ & $1.60 \mathrm{E}-4$ & $1.60 \mathrm{E}-4$ & $1.60 \mathrm{E}-4$ & $1.60 \mathrm{E}-4$ & $1.60 \mathrm{E}-4$ & $1.62 \mathrm{E}-4$ & $8.80 \mathrm{E}-4$ \\
\hline & $0.08 \%$ & $0.08 \%$ & $0.09 \%$ & $0.09 \%$ & $0.09 \%$ & $0.06 \%$ & $0.09 \%$ & $0.13 \%$ \\
\hline \multirow[t]{2}{*}{${ }^{54} \mathrm{Mn}$} & $1.04 \mathrm{E}-4$ & $1.09 \mathrm{E}-4$ & $1.04 \mathrm{E}-4$ & $1.05 \mathrm{E}-4$ & $1.03 \mathrm{E}-4$ & $1.02 \mathrm{E}-4$ & $1.03 \mathrm{E}-4$ & $1.25 \mathrm{E}-4$ \\
\hline & $0.06 \%$ & $0.06 \%$ & $0.06 \%$ & $0.06 \%$ & $0.06 \%$ & $0.04 \%$ & $0.05 \%$ & $0.02 \%$ \\
\hline \multirow[t]{2}{*}{${ }^{58} \mathrm{Co}$} & $2.50 \mathrm{E}-4$ & $3.22 \mathrm{E}-4$ & $2.36 \mathrm{E}-4$ & $2.44 \mathrm{E}-4$ & $2.38 \mathrm{E}-4$ & $2.34 \mathrm{E}-4$ & $2.40 \mathrm{E}-4$ & $2.82 \mathrm{E}-4$ \\
\hline & $0.13 \%$ & $0.17 \%$ & $0.13 \%$ & $0.13 \%$ & $0.13 \%$ & $0.09 \%$ & $0.13 \%$ & $0.04 \%$ \\
\hline \multirow[t]{2}{*}{${ }^{60} \mathrm{Co}$} & $3.32 \mathrm{E}-3$ & $3.40 \mathrm{E}-3$ & $3.30 \mathrm{E}-3$ & $3.34 \mathrm{E}-3$ & $3.30 \mathrm{E}-3$ & $3.30 \mathrm{E}-3$ & $3.32 \mathrm{E}-3$ & $3.92 E-3$ \\
\hline & $1.76 \%$ & $1.80 \%$ & $1.79 \%$ & $1.84 \%$ & $1.82 \%$ & $1.21 \%$ & $1.77 \%$ & $0.58 \%$ \\
\hline \multirow[t]{2}{*}{${ }^{89} \mathrm{Sr}$} & $1.53 \mathrm{E}-5$ & $9.30 \mathrm{E}-5$ & $4.04 \mathrm{E}-5$ & $4.96 \mathrm{E}-6$ & $4.96 \mathrm{E}-6$ & $4.96 \mathrm{E}-6$ & $4.96 \mathrm{E}-6$ & $3.90 \mathrm{E}-4$ \\
\hline & $0.00 \%$ & $0.05 \%$ & $0.02 \%$ & $0.00 \%$ & $0.00 \%$ & $0.00 \%$ & $0.00 \%$ & $0.06 \%$ \\
\hline${ }^{90} \mathrm{Sr}$ & $1.45 \mathrm{E}-4$ & $1.21 \mathrm{E}-4$ & $2.36 \mathrm{E}-3$ & $7.14 \mathrm{E}-6$ & $7.14 \mathrm{E}-6$ & $7.14 \mathrm{E}-6$ & $7.14 \mathrm{E}-6$ & $2.56 \mathrm{E}-4$ \\
\hline & $0.08 \%$ & $0.06 \%$ & $1.28 \%$ & $0.00 \%$ & $0.00 \%$ & $0.00 \%$ & $0.00 \%$ & $0.04 \%$ \\
\hline${ }^{134} \mathrm{Cs}$ & $4.42 \mathrm{E}-4$ & $4.52 \mathrm{E}-4$ & $4.42 \mathrm{E}-4$ & $4.44 \mathrm{E}-4$ & $4.42 \mathrm{E}-4$ & $4.40 \mathrm{E}-4$ & $4.36 \mathrm{E}-4$ & $5.66 \mathrm{E}-4$ \\
\hline & $0.23 \%$ & $0.24 \%$ & $0.24 \%$ & $0.24 \%$ & $0.24 \%$ & $0.16 \%$ & $0.23 \%$ & $0.08 \%$ \\
\hline${ }^{137} \mathrm{Cs}$ & $1.54 \mathrm{E}-3$ & $1.58 \mathrm{E}-3$ & $1.55 \mathrm{E}-3$ & $1.54 \mathrm{E}-3$ & $1.54 \mathrm{E}-3$ & $1.54 \mathrm{E}-3$ & $1.54 \mathrm{E}-3$ & $4.88 \mathrm{E}-3$ \\
\hline & $0.82 \%$ & $0.83 \%$ & $0.84 \%$ & $0.85 \%$ & $0.85 \%$ & $0.56 \%$ & $0.82 \%$ & $0.71 \%$ \\
\hline "TOTAL ${ }^{*}$ & $1.89 \mathrm{E}-1$ & $1.89 \mathrm{E}-1$ & $1.85 \mathrm{E}-1$ & $1.82 \mathrm{E}-1$ & $1.82 \mathrm{E}-1$ & $2.74 \mathrm{E}-1$ & $1.88 \mathrm{E}-1$ & $6.82 \mathrm{E}-1$ \\
\hline
\end{tabular}


Table 3. Calculation results for the annual total effective dose to individual for three agegroups: child, teenager and adult at the locations of interest.

\begin{tabular}{|c|c|c|c|c|c|}
\hline \multirow{2}{*}{ Location } & \multirow{2}{*}{ Direction } & \multirow{2}{*}{ Distance $(\mathrm{km})$} & \multicolumn{3}{|c|}{$\begin{array}{l}\text { Annual total effective dose to } \\
\text { individual for age groups (mSv) for age groups }\end{array}$} \\
\hline & & & Adult & Teenager & Child \\
\hline VinhTuong (Thuan Nam) & $\mathrm{N}$ & 1.165 & $3.55 \mathrm{E}-04$ & $4.69 \mathrm{E}-04$ & $8.19 \mathrm{E}-04$ \\
\hline Son Hai (Thuan Nam) & S & 2.18 & $6.35 \mathrm{E}-04$ & $8.20 \mathrm{E}-04$ & $1.40 \mathrm{E}-03$ \\
\hline Tu Thien (Thuan Nam) & $\mathrm{N}$ & 3.38 & $6.64 \mathrm{E}-05$ & $8.60 \mathrm{E}-05$ & $1.47 \mathrm{E}-04$ \\
\hline Bau Ngu (Thuan Nam) & NW & 5.9 & $9.92 \mathrm{E}-05$ & $1.30 \mathrm{E}-04$ & $2.25 \mathrm{E}-04$ \\
\hline HoaThuy (Ninh Phuoc) & NNW & 9.1 & $2.68 \mathrm{E}-05$ & $3.31 \mathrm{E}-05$ & $5.33 \mathrm{E}-05$ \\
\hline Phuoc Lap (Thuan Nam) & NW & 11.25 & $4.81 \mathrm{E}-05$ & $6.00 \mathrm{E}-05$ & $9.76 \mathrm{E}-05$ \\
\hline Quan The (Thuan Nam) & $\mathrm{W}$ & 12.5 & $1.90 \mathrm{E}-05$ & $2.34 \mathrm{E}-05$ & $3.74 \mathrm{E}-05$ \\
\hline Hieu Thien (Thuan Nam) & WNW & 13.45 & $2.20 \mathrm{E}-05$ & $2.81 \mathrm{E}-05$ & $4.73 \mathrm{E}-05$ \\
\hline Thuong Diem (Thuan Nam) & SW & 15.48 & $6.81 \mathrm{E}-05$ & $8.94 \mathrm{E}-05$ & $1.55 \mathrm{E}-04$ \\
\hline Lac Tien (Thuan Nam) & WSW & 14.42 & $1.83 \mathrm{E}-05$ & $2.29 \mathrm{E}-05$ & $3.75 \mathrm{E}-05$ \\
\hline Ca Na (Thuan Nam) & SW & 16.79 & $6.12 \mathrm{E}-05$ & $8.04 \mathrm{E}-05$ & $1.39 \mathrm{E}-04$ \\
\hline Phan Rang-Thap Cham & $\mathrm{N}$ & 14.2 & $1.51 \mathrm{E}-05$ & $1.78 \mathrm{E}-05$ & $2.68 \mathrm{E}-05$ \\
\hline Lien Huong (Tuy Phong) & SW & 38.75 & $1.76 \mathrm{E}-05$ & $2.22 \mathrm{E}-05$ & $3.71 \mathrm{E}-05$ \\
\hline Phong Phu (Tuy Phong) & WSW & 43.6 & $4.82 \mathrm{E}-06$ & $5.73 \mathrm{E}-06$ & $8.78 \mathrm{E}-06$ \\
\hline Phan Đien (Bac Binh) & WSW & 58.5 & $3.23 \mathrm{E}-06$ & $3.80 \mathrm{E}-06$ & $5.72 \mathrm{E}-06$ \\
\hline Cho Lau (Bac Binh) & WSW & 60.9 & $3.10 \mathrm{E}-06$ & $3.64 \mathrm{E}-06$ & $5.45 \mathrm{E}-06$ \\
\hline Thanh My (Don Duong) & NW & 66.3 & $3.96 \mathrm{E}-06$ & $4.67 \mathrm{E}-06$ & $7.07 \mathrm{E}-06$ \\
\hline To Hap (Khanh Son) & $\mathrm{N}$ & 63.6 & $1.99 \mathrm{E}-06$ & $2.28 \mathrm{E}-06$ & $3.29 \mathrm{E}-06$ \\
\hline Cam Ranh & NNE & 62.4 & $2.75 \mathrm{E}-06$ & $3.29 \mathrm{E}-06$ & $5.09 \mathrm{E}-06$ \\
\hline Lien Nghia (Duc Trong) & WNW & 78 & $1.90 \mathrm{E}-06$ & $2.27 \mathrm{E}-06$ & $3.48 \mathrm{E}-06$ \\
\hline
\end{tabular}

the data on agricultural production activities, the terrain data and the meteorological data in the five-year period 2009-2013.

The obtained calculation results for the annual integrated population dose and the annual individual dose at the specific locations within the $80 \mathrm{~km}$ radius from the site of NPP Ninh Thuan 1 showed that under a normal operation scenario with the routine release of radioactive nuclides from the NPP to the atmosphere all the dose values are much less than the limit value for publics.

The $X / Q$ value and $D / Q$ value distributions which are predominant in two directions of North East and South West are consistent with the wind rose distribution within the $80 \mathrm{~km}$ radius from the plant site.

\section{Acknowledgements}

This work has been performed in frame work of the National Program on Science and Technology in 2011-2015 Period under grant no. KC-05.04/11-15.

\section{References}

[1] UNSCEAR 2000 Report Vol. 1, Exposures from Man-Made Sources of Radiation.

[2] UNSCEAR 2008 Report Vol. 2, Radiation Exposures in Accidents.

[3] Sagendorf, J.F., Goll, J.T. and Sandusky, W.F. (1982) XOQDOQ: Computer Program for the Meteorological Evalua- 
tion of Routine Releases at Nuclear Power Stations. NUREG/CR-2919, US Nuclear Regulatory Commission, Washington DC.

[4] Strenge, D.L., Bander, T.J. and Soldat, J.K. (1987) GASPAR II-Technical Reference and User Guide. NUREG/CR4653, US Nuclear Regulatory Commission, Washington DC.

[5] (1977) Regulatory Guide 1.109—Calculation of Annual Doses to Man from Routine Releases of Reactor Effluents for the Purpose of Evaluating Compliance with 10 CFR Part 50, Appendix I. US Nuclear Regulatory Commission.

[6] (1977) Regulatory Guide 1.111-Methods for Estimation Atmospheric Transport and Dispersion of Gaseous Effluents in Routine Releases from Light-Water-Cooled Reactor. US Nuclear Regulatory Commission.

[7] Pasquill, F. (1974) Atmospheric Diffusion. Halsted Press, New York.

[8] Quinn, W.H. and Burt, W.V. (1967) Computation of Incoming Radiation over the Equatorial Pacific. Journal of Applied Meteorology.

[9] Subpart, D. Radiation Dose Limits for Individual Members of the Public. Part 20-Standards for Protection against Radiation, NRC Regulations (10 CFR).

[10] (2014) The Vietnam Ministry of Science and Technology (MOST) on Preparing and Planning the Emergency Preparedness for Radiation and Nuclear Accidents. Circular No. 25/2014/TT-BKHCN.

[11] Manual for Reactor Produced Radioisotopes, IAEA-TECDOC-1340, Vienna.

[12] UNSCEAR 2013 Report, Volume II, Scientific Annex B: Effects of Radiation Exposure of Children.

[13] Age-Dependent Doses to Members of the Public from Intake of Radionuclides: Part 1, Pergamon Press, 1989. 